author's knowledge was based on a thoroughly practical acquaintance with the animals with which he dealt. While we fully admit the difficulties of the task of compilation of the second, the present work, we regret we cannot recommend it with the confidence extended to its predecessor.

\section{THE PROBLEM OF TRUTH.}

Das Wahrheitsproblem unter Kulturphilosophischem Gesichtspunkt-Eine philosophische,Skizze. Von Dr. Hermann Leser. Pp. iv +90 . (Leipzig: Dürr'sche Buchhandlung, I90I.) Price 2 marks.

THE author of this work is not a "jesting Pilate." His book contains rather a thorough discussion of the problem of truth in some of its widest issues. The standpoint is essentially Kantian, but with a difference. The question raised in the "Critique of Pure Reason" was, How are pure mathematical science and pure natural science possible?--in other words, on what principles can it be maintained that the ordinary experience of man quît intellectual gives him truth? Dr. Leser contends that the problem should be stated more widely in the form, How is truth in general possible, the truth of all the higher spiritual life of man, of religion, morality, art, as well as science? And it is claimed for the work before us that, as compared with Kant's, it is more concrete in treatment, that it goes nearer the heart of things, and that while including and remaining true to Kant's results it gives a more satisfactory basis for future development.

The first part deals with a deepened idea of experience, for which the author employs the term "Kulturhistorische Erfahrung." By this he appears to mean the higher spiritual experience of the race as exhibited by history in such things as institutions, codes, systems, standards of judgment. In the development of this view, naturalism is subjected to some telling criticism. Finding nothing anywhere but "bare results, finer complications of natural process," naturalism would exclude all facts which do not coincide with, or cannot be reduced to, the facts of ordinary natural science. In dealing with the institutions in which the spiritual life has found expression, naturalism pays regard only to the crystallised form, not to the spiritual potencies which have been at work. It attaches exclusive value to what is genetically original, and denies, for example, the characteristic distinction between good and bad by deriving it from the distinction between the useful and the harmful. Such a psychogenetic method can never get beyond brutal actuality to norms or standards of judgment; it is only a transcendental method (the author maintains) which can disclose the organisation of "rulers and subjects," for example, the subordination of what is first in time to what is ideally fundamental.

The latter part of the book is concerned with the problem of truth from the new standpoint thus gained. It is pointed out that Kant replaced the old objectivity (supposed to exist entirely out of relation to a subject) by transcendental-subjectivity, than which no more secure objectivity can be found. This means that truth is to be found by "turning to one's own depths"; but if it is to be depths and not shallows, to be transcendental-subjectivity in the right sense and not bare subjectivity in the wrong sense, we must have recourse to "Kulturhistorische Erfahrung." It is only as experience is writ thus large that the potencies at work can be discovered. One of the chief of these potencies is personality. Personality Dr. Leser opposes on the one hand to bare individualism, and on the other to the equally bare disregard of the personal factor. The great man is neither the heavensent hero dear to the soul of a Carlyle nor the hollow pipe through which the "Zeitgeist" pours such music as it listeth. Or, as our author puts the latter point: "The man is more than the product of his time; planting himself on the original truth which he has found within him, it is he who first makes a new height attainable."

The work is not unnecessarily stiff. At times, perhaps, a little vagueness is felt, and the technical terms, as usual, can rarely be translated by single words. But his readers will doubtless welcome another book from this careful and suggestive writer. R. G. N.

\section{OUR BOOK SHELF.}

Catalogue of the Lepidoptera Phalaenae in the British Museum. Vol. iii. "Catalogue of the Arctiadæe (Arctianæ) and Agaristidæ in the Collection of the British Museum." By Sir George F. Hampson, Bart. Pp. xix +690 . Plates xxxvi-liv. (London: Printed by Order of the Trustees, I90I.)

FOR a long time after the study of exotic butterflies began to grow popular in England, that of moths continued to be much neglected, though moths, taken as a whole, are equally beautiful and far more numerous than the butterflies. But after the pathway had been smoothed by the useful, though much abused, catalogue of Walker, the works of Moore, Butler and Druce, and especially by Kirby's "Catalogue of Lepidoptera Heterocera : Sphinges and Bombyces," published in 1892 , the Trustees of the British Museum decided to issue a general descriptive catalogue of the moths of the world, which bids fair to becorne one of the largest and most profusely illustrated of all their publications on natural history.

The work was entrusted to Sir George F. Hampson and three thick volumes have already been issued. According to the table of families in vol. i. the author admits fifty-two, which, deducting seven for the butterflies, leaves forty-five for the moths, of which only the first three are monographed in the portion of the work already published, so that little more than the fringe of the subject has yet been touched. Of course some of these families only include a few species; but, on the other hand, there are several very much more extensive than the Arctiadæ, which alone fill up the greater part of vols. ii. and iii. The plates are published separately, and can be bought separately, a useful arrangement which will enable students who require an additional copy of the book for working purposes to purchase it without the additional and unnecessary cost of a duplicate set of coloured plates. In addition to these coloured plates, drawn by Mr. Horace Knight and chromolithographed by West, Newman and Co., the book is further illustrated by text-illustrations of types of genera, showing both the pattern and the most important generic details, and of these compound figures there are no less than 294 in vol. iii., in which 946 Arctianx and 225 Agaristidæare described, of which a considerable number are new species. At the end of the volume is a short list of species which the author has not been able to identify from the published descriptions. Should further information respecting these be forthcoming, we presume that

No. I 680 , VOL. 65] 